\section{Micropropagation of the Fiber-rich Amazonian Species Ananas erectifolius (Bromeliaceae)}

\author{
Flávia D. Pereira, José Eduardo B.P. Pintoํㅜ, Luciana D.S. Rosado, \\ Helen C.A. Rodrigues, Suzan K.V. Bertolucci, and Osmar A. Lameira \\ Laboratório de Cultura de Tecidos e Plantas Medicinais, Universidade \\ Federal de Lavras, 37200-000, Lavras, MG, Brazil
}

Additional index words. etiolated shoots, in vitro micropropagation, fiber source

\begin{abstract}
The aim of the study was to develop a method for the in vitro propagation of Ananas erectifolius (Bromeliaceae), a fiber-rich Amazonian species. In vitro cultures were established from axillary buds of field-grown plants cultured on medium without plant growth regulators (PGRs). Stumps were excised from in vitro plantlets and incubated under dark conditions on medium supplemented with different combinations of 1-naphthaleneacetic acid (NAA), kinetin, and gibberellic acid (GA G $_{3}$. The most efficient induction of etiolated shoots occurred on explants cultured in the presence of NAA at $10.74 \mu M$ (T1 medium) or NAA at $5.37 \mu M+G_{3}$ at $3 \mu M$ (T2 medium). Apical tips and nodal segments of the etiolated shoots were recultured under a $16-h$ photoperiod in medium without PGRs, and the effects of residual PGRs were evaluated by determining the numbers and lengths of plantlets that regenerated within 30 days. Residual PGRs exhibited no effect on the length of the regenerated plantlets but significantly affected the number of plantlets regenerated from nodal segments but not from apical tips. Nodal segments and apical tips derived from etiolated shoots produced, respectively, on T2 and T1 medium were most appropriate for plantlet regeneration. Nearly all $(\mathbf{9 8 \%})$ regenerated plantlets formed roots when cultured in liquid medium without PGRs, and all plantlets survived acclimatization under greenhouse conditions. The stumps originating from etiolated shoots regenerated new etiolated shoots when recultured in the dark on medium without PGRs, thus providing a supply of new explants for plant regeneration.
\end{abstract}

The species Ananas erectifolius (L.B.Sm) (Bromeliaceae) is native to the Amazon region where it is known locally as "curauá" and finds application over a diverse range of purposes. The plant grows in poor sandy soil, attains a height of between 1 and $1.5 \mathrm{~m}$, and produces 12 to 15 leaves that are very rich in lignocelluloses. Typically, the leaves of each plant yield $\approx 2 \mathrm{~kg}$ of fiber (Ramalho, 2005).

After edible and medicinal plants, fiberproducing species form the next most useful group of plants for humankind. Within Brazil alone, it is estimated that the market for natural fibers is responsible for more than one million jobs in economically undeveloped areas. Furthermore, the emergence of novel ecological plant materials has enhanced the prospects of creating a better quality of life for small producers working in such areas (Ramalho, 2005). In this respect, the fiber of $A$. erectifolius is not only a valuable raw material for the local manufacture of domestic utensils and decorative

Received for publication 25 June 2008. Accepted for publication 12 Aug. 2008.

We thank the Conselho Nacional de Desenvolvimento Científico e Tecnológico (CNPq) and FAPEMIG for financial support (scholarships and research grants) and Mr. José Fábio Camolesi for assistance with the construction of Figure 1.

${ }^{1}$ To whom reprint requests should be addressed; e-mail jeduardo@ufla.br objects, but has huge industrial potential in the automobile industry and in civil construction. For example, recent studies have indicated that, by virtue of the excellent properties of resistance, lightness, and softness of its fiber, A. erectifolius is particularly suitable for use in the internal trimming of cars (i.e., seat covers and carpets). However, the extensive industrial application of $A$. erectifolius fiber is limited by the scarce supply of the raw material because the plant will only develop in a warm and humid climate, thus creating problems in the acquisition of propagative material outside of such regions (Silva, 2004).

To overcome the limitations of conventional agricultural methods and to develop protocols to enable plants to grow in different environments, micropropagation techniques can be used to produce large quantities of rooted and disease-free propagules. Plants that have been micropropagated in the partial or complete absence of light form micropropagules that produce no chlorophyll (and are hence pale yellow in color), develop long, thin stems, small, sparse leaves, and elongated internodes. Etiolation offers the advantages of promoting the development of axillary buds and reducing the level of fungal and viral infection at the apices. Such explants are thus more likely to be pathogen-free. Kiss et al. (1995) developed a method for the micropropagation of $A$. como- sus L. Merr (pineapple) involving etiolation together with the addition of growth regulators in the culture medium to bring about elongation of the internodes and subsequent plant regeneration at the cut nodes. Micropropagation of etiolated explants has been applied to a number of plant species, including alfalfa (Dudits et al., 1991), tobacco (Maliga et al., 1975), and pineapple (Pereira et al., 2001). However, whereas etiolation preserves the genetic stability of the explants (which is not necessarily the case when growth regulators are used), the application of the method is limited because some species present unusual growth habits and restricted levels of multiplication under such conditions.

In view of the commercial potential of $A$. erectifolius and the need to increase our knowledge base regarding the culture of this valuable but little studied species, we present a method for the micropropagation of etiolated shoots of curauá and their regeneration into fully developed plants. The factors influencing the growth and multiplication of $A$. erectifolius are discussed.

\section{Materials and Methods}

Establishment of axillary bud in vitro cultures. Plants of A. erectifolius (L.B.Sm) were obtained from the Botanical Garden of Embrapa Amazônia Oriental (Belém, PA, Brazil) and authenticated by Dr. A.C.O. Azulino. A voucher specimen is deposited in the herbarium with the reference number N. 1 (IAN 178667). Axillary buds obtained from plants grown in the field were immersed, with constant agitation, in $70 \%$ ethanol for $1 \mathrm{~min}$ followed by commercial bleach (2.5\% sodium hypochlorite) for 30 min. The explants were rinsed six times with sterile distilled water and placed in pots containing semisolid Murashige and Skoog (MS) medium (Murashige and Skoog, 1962) $(0.7 \%$ agar $)$ in the absence of plant growth regulators (PGRs) and incubated in the light ( 25 to $30 \mu \mathrm{mol} \cdot \mathrm{m}^{-2} \cdot \mathrm{s}^{-1}$ ) supplied by cold fluorescent bulbs at $26 \pm 1{ }^{\circ} \mathrm{C}$ for $20 \mathrm{~d}$. All manipulations were conducted in a laminar flow cabinet in the vicinity of a Bunsen burner. Plants derived from axillary buds were used as a source of explants for Phase I experiments.

Induction of etiolated shoots (Phase I). Leaves from in vitro-derived plants were removed and the plantlets cut 5 to $8 \mathrm{~mm}$ above the stumps. The explants were transferred to glass jars $(12 \mathrm{~cm} \times 5.5 \mathrm{~cm}$ in diameter) containing $15 \mathrm{~mL}$ of semisolid MS medium $(0.6 \%$ agar) that had been supplemented with different amounts of PGRs (treatments T1 to T4 as shown in Table 1) and adjusted to $\mathrm{pH} 5.7 \pm 0.1$ before autoclaving at $1.1 \mathrm{~kg} \cdot \mathrm{cm}^{-2}, 121{ }^{\circ} \mathrm{C}$, for 15 min. Cultures were incubated in the dark in a growth room maintained at $26 \pm 1^{\circ} \mathrm{C}$ for $40 \mathrm{~d}$, after which period the numbers and lengths of shoots were determined. The etiolated shoots were used as sources of explants for Phase II experiments. 
Table 1. Plant growth regulators on the formation of etiolated shoots from explants of $A$. erectifolius (Phase I experiments) after $30 \mathrm{~d}$ of incubation.

\begin{tabular}{llcc}
\hline & \multicolumn{1}{c}{ Plant growth regulators used } & \multicolumn{2}{c}{ Etiolated shoots $^{\mathrm{y}}$} \\
\cline { 3 - 4 } Treatment & NAA $(10.74 \mu \mathrm{M})$ & Number & Length $(\mathrm{cm})^{\mathrm{z}}$ \\
\hline T1 & NAA $(5.37 \mu \mathrm{M})+\mathrm{GA}_{3}(3.0 \mu \mathrm{M})$ & $3.73^{\mathrm{A}}$ & $8.54^{\mathrm{A}}$ \\
T2 & NAA $(5.37 \mu \mathrm{M})+\mathrm{GA}_{3}(3.0 \mu \mathrm{M})+\mathrm{KIN}(2.32 \mu \mathrm{M})$ & $3.76^{\mathrm{A}}$ & $8.10^{\mathrm{A}}$ \\
T3 & NAA $(10.74 \mu \mathrm{M})+\mathrm{KIN}(2.32 \mu \mathrm{M})$ & $4.10^{\mathrm{A}}$ & $6.13^{\mathrm{B}}$ \\
T4 &
\end{tabular}

${ }^{\mathrm{z}}$ Shoots were induced in the dark at $26 \pm 1^{\circ} \mathrm{C}$ on Murashige and Skoog medium supplemented with the plant growth regulators indicated.

${ }^{\mathrm{y}}$ In each column, mean values $(\mathrm{n}=40)$ bearing different superscript letters were significantly different according to the Scott-Knot test $(P \leq 0.05)$.

$\mathrm{NAA}=1$-naphthaleneacetic acid; $\mathrm{GA}_{3}=$ gibberellic acid; $\mathrm{KIN}=$ kinetin.

Axillary shoot formation from etiolated shoots (Phase II). Etiolated shoots were cut into three portions, namely, the apical tip, the midportion (nodal segment), and the basal portion (stump). Apical tips and nodal segments $(1.5$ to $2.0 \mathrm{~cm})$ were placed into glass jars $(9.5 \mathrm{~cm} \times 5.5 \mathrm{~cm}$ in diameter) containing $15 \mathrm{~mL}$ of liquid MS medium, without PGRs, and incubated with constant agitation at 85 rpm under a 16-h photoperiod in a growth room maintained at $26 \pm 1{ }^{\circ} \mathrm{C}$. The stumps were reinoculated into $15 \mathrm{~mL}$ of semisolid MS medium ( $0.6 \%$ agar), without PGRs, and incubated in the dark in a growth room maintained at $26 \pm 1{ }^{\circ} \mathrm{C}$. After $30 \mathrm{~d}$ incubation, the effects of residual PGRs were assessed by determining the numbers and lengths of the plantlets and etiolated shoots regenerated from the different types of explants.

Rooting and acclimatization (hardening). Rooting was induced by placing the plantlets in semisolid MS medium ( $0.6 \%$ agar), without PGRs, and incubating the flasks under a 16-h photoperiod (light intensity of 25 to 30 $\mu \mathrm{mol} \cdot \mathrm{m}^{-2} \cdot \mathrm{s}^{-1}$ supplied by cold fluorescent bulbs) in a growth room maintained at $26 \pm$ $1{ }^{\circ} \mathrm{C}$. When the plantlets attained 4 to $6 \mathrm{~cm}$ in length, they were removed from the medium and their roots were washed gently under the tap. Propagules were placed in plastic trays containing Plantmax compost (Eucatex, Jundiaí, SP, Brazil) and incubated in the greenhouse at ambient temperature, $50 \%$ shading, and $80 \%$ humidity.

Statistical analysis. Both Phase I and II experiments followed a randomized design in which each treatment consisted of three sets of flasks, 10 repetitions per set, four flasks per repetition, and four explants per flask. Statistical analyses were carried out with the aid of SISVAR statistical software (Ferreira, 2003). Data were submitted to analysis of variance and $\mathrm{F}$ tests, and mean values were compared using the Scott-Knot test. Differences between treatments were considered significant at $P \leq 0.05$.

\section{Results and Discussion}

Establishment of axillary bud in vitro cultures. Axillary buds obtained from plants grown in the field were successfully established in medium. Bacterial and fungal contamination rates were $20 \%$. Prathanturarug et al. (2007) showed bacterial and fungal contamination rates of Mallotus repandus of $9.8 \%$ and $0.4 \%$, respectively. We speculate that the establishment of contamination-free axillary buds explants was dependent on well-treated donor plants. The shoots were developed from axillary buds $(90 \%)$ within $30 \mathrm{~d}$ on the MS medium with free-growth regulator (Fig. 1, step 1).

Induction of etiolated shoots (Phase I). The present study provides a method for high-frequency etiolated shoots from stumps of $A$. erectifolius. Etiolated shoots formed from stumps of $A$. erectifolius that had been incubated on medium containing different levels and combinations of the PGRsnaphthaleneacetic acid (NAA), gibberellic acid $\left(\mathrm{GA}_{3}\right)$, and kinetin (KIN) (Table 1)-were pale in color with greenish bases, long internodes, and no roots (Fig. 1, steps 2 to 4). Etiolated shoots grew from the stumps after 25 to $30 \mathrm{~d}$ of dark incubation (Fig. 1, steps 3 and 4). Kiss et al. (1995) showed etiolated shoots formation in Ananas comosus after 10 to $14 \mathrm{~d}$. We speculate the fast induction in pineapple was the result of the stumps being used were rooted so the roots can help more absorption of micro- and macronutrients from the medium. No significant differences were observed in the numbers of etiolated shoots that formed under the different PGR regimes applied, although the average lengths of the etiolated shoots produced under treatments supplemented with $\mathrm{NAA}$ (T1) and NAA + GA (T2) were significantly greater $(P \leq 0.05)$ than those generated under treatments supplemented with kinetin together with NAA + GA (T3) or NAA (T4) (Table 1). The most appropriate medium for the induction of etiolated shoots contained NAA at $10.74 \mu \mathrm{M}$ (T1) or NAA at $5.37 \mu \mathrm{M}+\mathrm{GA}_{3}$ at $3 \mu \mathrm{M}$ (T2). There was more than one (mean, 3.83) etiolated shoot per stump developed; we speculate that these were of axillary bud origin from base each leaf. Kiss et al. (1995) concluded that these shoots had adventitious origin. By the 30th day, shoot length had reached 6.13 to $8.54 \mathrm{~cm}$ (mean, $7.29 \mathrm{~cm}$ ) (Table 1).

The average numbers and lengths of etiolated shoots obtained in the present study were greater than those reported by Barboza and Caldas (2001) after experiments with the hybrid pineapple $\mathrm{PE} \times \mathrm{SC}-52$. In this study, the average numbers of etiolated shoots formed from explants grown on MS medium containing NAA $(10 \mu \mathrm{M})$, indole acetic acid
$(10 \mu \mathrm{M})$, or no PGRs were $1.5,1.5$, and 1.4 , respectively, and their average lengths were $5.5,4.8$, and $4.8 \mathrm{~cm}$, respectively.

Axillary shoot formation from etiolated shoots (Phase II). Etiolated shoots harvested at $30 \mathrm{~d}$ were cut into three portions - apical tips, nodal segments, and stumps - and subcultured onto MS medium without PGRs. Exposure to light in the absence of PGRs induced the further development of the axillary buds on both apical tips and nodal segments excised from etiolated shoots of A. erectifolius. The plantlets regenerated from these portions were well-formed, vigorous, and exhibited few roots. The presence of white fibers could be detected by the naked eye and conferred a tough, firm appearance to the leaves. The presence of clusters, calluses, or morphological alterations was not observed in the regenerated plantlets (Fig. 1, steps 5 to 7).

Axillary shoot formation from apical tips. The regeneration of plantlets from apical tips is not often applied in micropropagation because these portions are normally removed and discarded to break apical dominance. In the present study, however, all parts of the etiolated shoots were tested as sources of explants for plantlet regeneration. We did not show any callus formation. The omission of callus production may reduce the problems of genetic instability during multiplication. As shown in Table 2, the average numbers and lengths of plantlets regenerated from apical tips were not significantly influenced by the residual concentrations of PGRs present in the explants derived from Phase I. Although differences were not statistically significant, it was, however, possible to perceive some effects of residual PGRs. Thus, apical tips originating from etiolated shoots produced under treatments $\mathrm{T} 1$ and $\mathrm{T} 2$, in which an auxin was used either alone or in combination with a gibberellin, gave rise to a larger number of plantlets compared with explants originating from shoots produced under treatments T3 and T4 in which a cytokinin was present. On the other hand, elongation, rather than multiplication, of plantlets regenerated from apical tips was favored in etiolated shoots that had been subjected to treatments T3 and T4. In terms of efficient plantlet regeneration, the most appropriate explants were those derived from apical tips of etiolated shoots produced on medium containing NAA at $10.74 \mu \mathrm{M}$ (T1).

Shoot proliferation from nodal segments. Residual PGRs significantly influenced the shoot proliferation from nodal segments as can be observed in Table 2. Thus, the numbers of plantlets regenerated from $\mathrm{T} 2$ and $\mathrm{T} 3$ explants (both of which had received treatment involving $\mathrm{GA}_{3}$ ) were greater than those produced from T1 and T4 explants. On the other hand, all of the regenerated plantlets presented similar lengths irrespective of residual PGRs. For efficient plantlet regeneration from nodal segments, the most suitable explants were those derived from etiolated shoots grown in $\mathrm{T} 2(5.37 \mu \mathrm{M} \mathrm{NAA}+3 \mu \mathrm{M}$ $\mathrm{GA}_{3}$ ). 


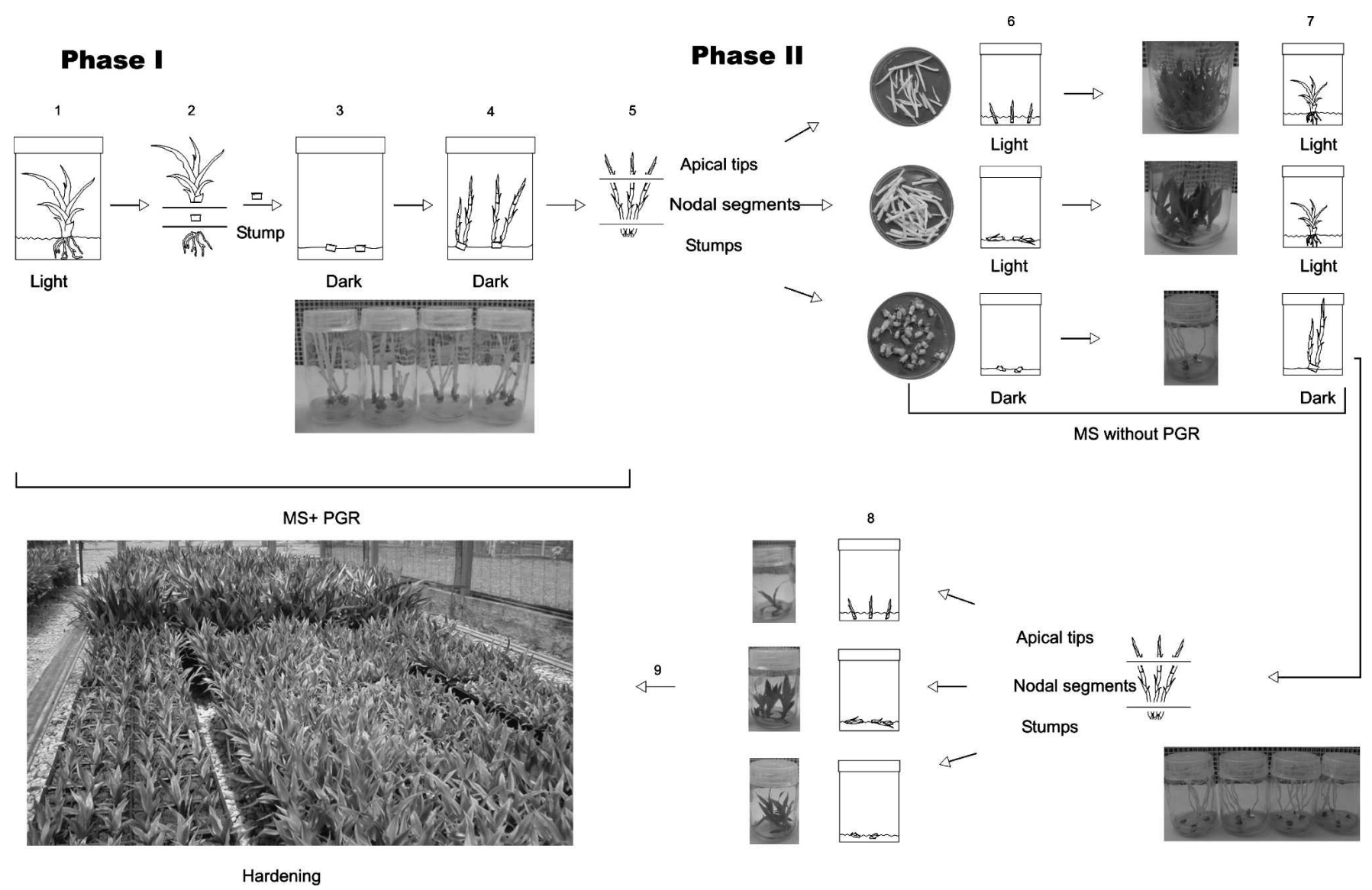

Fig. 1. Micropropagation of A. erectifolius: (1) establishment of in vitro cultures; (2) excision of stumps; (3) culture of stumps on Murashige and Skoog (MS) medium supplemented with plant growth regulators; (4) formation of etiolated shoots; (5) excision of apical tips, nodal segments, and stumps; (6) culture of explants in MS medium without plant growth regulators; (7) axillary shoot formation from apical tips and nodal segments and formation of new etiolated shoots from stumps; (8) shoot multiplication from stumps of etiolated shoots; and (9) hardening of micropropagules in the greenhouse.

Table 2. Regeneration of plantlets and shoots from different portions of etiolated shoots of $A$. erectifolius induced in Phase I experiments.

\begin{tabular}{|c|c|c|c|c|c|c|}
\hline \multirow[b]{3}{*}{$\begin{array}{l}\text { Explants excised } \\
\text { from etiolated shoots }\end{array}$} & \multicolumn{4}{|c|}{ Regenerated plantlets $y$} & \multirow{2}{*}{\multicolumn{2}{|c|}{ New shoots ${ }^{\mathrm{x}}$ Stumps $\mathrm{w}$}} \\
\hline & \multicolumn{2}{|c|}{ Apical tips $^{w}$} & \multicolumn{2}{|c|}{ Nodal segments $^{\mathrm{w}}$} & & \\
\hline & Number & $\begin{array}{c}\text { Length } \\
(\mathrm{cm})\end{array}$ & Number & $\begin{array}{c}\text { Length } \\
(\mathrm{cm})\end{array}$ & Number & $\begin{array}{l}\text { Length } \\
(\mathrm{cm})\end{array}$ \\
\hline From T1 & $18.50^{\mathrm{A}}$ & $4.13^{\mathrm{A}}$ & $2.85^{\mathrm{B}}$ & $3.91^{\mathrm{A}}$ & $7.00^{\mathrm{A}}$ & $12.65^{\mathrm{A}}$ \\
\hline From T2 & $21.50^{\mathrm{A}}$ & $3.36^{\mathrm{A}}$ & $3.91^{\mathrm{A}}$ & $4.36^{\mathrm{A}}$ & $6.83^{\mathrm{A}}$ & $11.34^{\mathrm{A}}$ \\
\hline From T3 & $12.66^{\mathrm{A}}$ & $4.90^{\mathrm{A}}$ & $3.66^{\mathrm{A}}$ & $4.26^{\mathrm{A}}$ & $6.80^{\mathrm{A}}$ & $11.79^{\mathrm{A}}$ \\
\hline From T4 & $12.00^{\mathrm{A}}$ & $4.14^{\mathrm{A}}$ & $2.69^{\mathrm{B}}$ & $3.74^{\mathrm{A}}$ & $5.80^{\mathrm{A}}$ & $10.21^{\mathrm{A}}$ \\
\hline
\end{tabular}

${ }^{\mathrm{z}}$ The treatments used were those shown in Table 1.

y Plantlets were regenerated under a 16-h photoperiod at $26 \pm 1{ }^{\circ} \mathrm{C}$ in Murashige and Skoog medium without plant growth regulators.

${ }^{\mathrm{x}} \mathrm{New}$ etiolated shoots were induced in the dark at $26 \pm 1^{\circ} \mathrm{C}$ on Murashige and Skoog medium without plant growth regulators.

${ }^{\mathrm{w}}$ In each column, mean values $(\mathrm{n}=40)$ bearing different superscript letters were significantly different according to the Scott-Knot test $(P \leq 0.05)$.

Whereas the influence of residual PGRs on the development of $A$. erectifolius explants could be detected (Table 2), other complex factors are also involved in plant regeneration in vitro. The capacity of explants to survive, multiply, and develop into adult plants depends on the genetic potential and physiological status of the explants, the endogenous concentrations of PGRs, and the environmental conditions applied to in vitro cultures. Moreover, an appropriate medium is required at each culture phase, because a concentration of nutrients is essential to pro- mote growth and the metabolic responses associated with differentiation (Kozai et al., 1997; Niedz and Evens, 2007). We observed that MS medium without any growth regulator did not fail to elicit shoot formation in contrast with Aegle marmelos that needs addition of cytokinin to shoot production in the node segment (Nayak et al., 2007).

The present study showed high-frequency plantlet formation using both explants from apical tips and nodal segments (mean, 9.7) without use of reused stumps. With this method, 85,000 plantlets can be formed with five or six multiplications during a year from one primary plant. Nayak et al. (2007) also showed high-frequency plantlet formation from node culture of Aegle marmelons. Our method is similar to that used for the micropropagation of pineapple (Kiss et al., 1995) and potato (Goodwin and Adisarwanto, 1980; Heszky and Nagy, 1987).

Etiolated shoots induction from reused stumps. All stumps originating from etiolated shoots produced further etiolated shoots when cultured under dark conditions on growth medium without PGRs (Table 2; Fig. 1, step $8)$. The residual PGRs present in the stumps originating from the etiolated shoots apparently exerted no influence on the numbers or lengths of the new etiolated shoots. However, the etiolated shoots formed in this phase had a greater number of internodes and thus presented a larger number of axillary buds for further plantlet regeneration. Normally the stumps are discarded, but the further culture of this portion is advantageous because more plantlets can be regenerated from the same plant stock without having to re-establish in vitro cultures. In this manner, the time and cost involved in the micropropagation of $A$. erectifolius can be greatly minimized.

Rooting and acclimatization (hardening). Plantlets often die during the transfer from in vitro to ex vitro conditions (Miceli et al., 2008). In the present study, most plantlets 
(98\%) regenerated from etiolated shoots produced roots when cultured in liquid MS medium in the absence of PGRs. When plantlets of $A$. erectifolius 3 to $5 \mathrm{~cm}$ high were transplanted to the commercial substratum Plantmax ${ }^{\circledR}$, the survival rate was $90 \%$ to $100 \%$. Souza et al. 2007 found that $L$. pinaster's survival rate was $0 \%$ in the commercial substratum Plantmax ${ }^{\circledR}$. We speculate that $A$. erectifolius did not need symbiotic microorganisms that allowed the transplants to survive as $L$. pinaster needs. Also, the size of the explant determines its survival during the rooting stage and acclimatization (George, 1996). In this study, the use of plastic bags to maintain the humidity in the first days of acclimatization was effective, because plantlets under this treatment grew well. All plantlets (100\%) survived the acclimatization period under greenhouse conditions (Fig. 1, step 9).

In conclusion, a reliable protocol for $A$. erectifolius micropropagation was developed under a relatively simple tissue culture regime. Etiolated shoots could be induced on explants of $A$. erectifolius incubated in the dark on MS medium supplemented with NAA, KIN, or combinations with $\mathrm{GA}_{3}$. The most efficient shoot induction occurred on explants cultured in the presence of NAA at $10.74 \mu \mathrm{M}(\mathrm{T} 1)$ or NAA at $5.37 \mu \mathrm{M}+\mathrm{GA}_{3}$ at $3 \mu \mathrm{M}$ (T2). Plantlets regenerated from apical tips and nodal segments excised from the etiolated shoots when cultivated in the light in MS medium without PGRs. Apical tips derived from etiolated shoots produced on T1 medium, and nodal segments derived from etiolated shoots produced on T2 medi- um, were most appropriate for plantlet regeneration. The stumps of the etiolated shoots could be induced to form new etiolated shoots, hence providing a further supply of explants for plant regeneration. The efficient rooting of regenerated plantlets was obtained by placing plantlets in liquid MS medium without PGRs.

\section{Literature Cited}

Barboza, S.B.S.C. and L.S. Caldas. 2001. Estiolamento e regeneração na multiplicação in vitro do abacaxizeiro híbrido PE $\times$ SC-52. Pesq. Agropec. Bras. 36:417-423.

Dudits, D., L. Borgre, and L. Gyorgyey. 1991. Embryo development from somatic plants cells in vitro: Molecular and cellular basis. J. Cel Sci. 1:473-482.

Ferreira, D.F. 2003. Programa Sisvar.exe Sistema de Análise de Variância-Versão 4.3. Lavras, UFLA.

George, E.F. 1996. Plant propagation by tissue culture: Part 1-The technology. Exegetics, Edington.

Goodwin, P.B. and T. Adisarwanto. 1980. Propagation of potato by shoot-tip culture in Petri dishes. Potato Res. 23:445-448.

Heszky, L.E. and M. Nagy. 1987. In vitro conservation of potato germplasm in Hungary, $\mathrm{p}$. 465-490. In: Bajaj, Y.P.S. (ed.). Biotechnology in agriculture and forestry 3, potato. SpringerVerlag, Berlin, Germany.

Kiss, E., J. Kiss, G. Gyulai, and L. Heszky. 1995. E. A novel method for rapid micropropagation of pineapple. HortScience 30:127-129.

Kozai, T., C. Kubota, and B.R. Jeong. 1997. Environmental control for the large-scale production of plants through in vitro techniques. Plant Cell Tiss. Org. Cult. 51:49-56.

Maliga, P., A.S. Breznovits, L. Márton, and F. Joó 1975. Non-Mendelian streptomycin-resistant tobacco mutant with altered chloroplasts and mitochondria. Nature 225:401-405.

Miceli, F.A.G., A.D. Estudillo, M.A. Archila, T.R.A. Talavera, and L. Dendooven. 2008. Optimization of Renealmia mexicana (Klotzsch ex. Petersen) cultivation in vitro. In Vitro Cell. Dev. Biol. Plant 44:33-39.

Murashige, T. and F. Skoog. 1962. A. Revised medium for rapid growth and bioassays with tobacco tissue cultures. Physiol. Plant 15:473479.

Nayak, P., P.R. Behera, and T. Manikkannan. 2007. High frequency plantlet regeneration from cotyledonary node culture of Aegle marmelos (L.) Corr. In Vitro Cell. Dev. Biol. Plant 43:231-236.

Niedz, R.P. and T.J. Evens. 2007. Regulating plant tissue growth by mineral nutrition. In Vitro Cell. Dev. Biol. Plant 43:370-381.

Pereira, F.D., M.F. Braga, M.E.L. Sá, O.G. Alcino, and I.C. Colenghi. 2001. Influência de BAP e NAA na multiplicação de abacaxi cv Perolera a partir de brotos estiolados in vitro. Biosci. J. 17:49-60.

Prathanturarug, S., N. Soonthornchareonnon, W Chuakul, Y. Phaidee, and P. Saralamp. 2007. An improved protocol for micropropagation of Mallotus repandus (Willd.) Mull. Arg. In Vitro Cell. Dev. Biol. Plant 43:275-279.

Ramalho, E. 2005. A folha amazônica que virou arte. 20 Aug. 2005 . <http://www.rfi.fr/actubr articles/068/article_124.asp>.

Silva, C. 2004. País pesquisa mais fibras naturais para carros. 25 Oct. 2004. <http://www.sebrae-sc. com.br/novos_destaques/oportunidade/default.asp? materia $=8356>$.

Souza, A.V., J.E.B.P. Pinto, S.K.V. Bertolucci, R.M. Corrêa, L.C.B. Costa, and W.E. Dyer. 2007. In vitro propagation of Lychnophora pinaster (Asteraceae): A threatened endemic medicinal plant. HortScience 42:16651669 . 